\title{
Effect of make in India on textile sector
}

\begin{abstract}
Government of India has embarked its highly ambitious programme 'Make in India' campaign to galvanise the manufacturing sector of the country and to increase the inward investment in different sectors. Textile industry, one of the largest and highly labour intensive manufacturing sectors in India, is one of the identified benefactors of this campaign. The present paper deals with the impact of Make in India scheme on the Textile and allied sectors. Indian yarn spinning sector occupy 24 percent of the world's spindles, and 8percent of the world's rotors. India is one of the few textile producing countries in the world which can claim the complete value chain productivity strength. The sector also has several advantages like, abundance of availability of raw materials like cotton and silk, and the comparative advantage in terms of skilled manpower. Make in India leads to penetration of organized retail, favorable demographics and rising income levels.
\end{abstract}

Keywords: make in india, indian textile industries
Volume 3 Issue I - 2017

\author{
Sujit Gulhane, Ranjit Turukmane \\ Centre for Textile Functions, Mukesh Patel School of Technology \\ Management and Engineering, India
}

Correspondence: Sujit Gulhane, Centre for Textile Functions, Mukesh Patel School of Technology Management and Engineering, SVKM'S NMIMS, Shirpur Campus, Dist. Dhule, Maharashtra, India, Email sujitgulhane.iitd@gmail.com

Received: April 24, 2017| Published: October 03, 2017

\section{Introduction}

The Indian Economy has been growing at an alarming fast rate. The near double-digit growth rate has been a trademark of Indian GDP growth since the early 2000's and is currently at influence with China. A majority of this high growth can be attributed to the public spending of the government, which has so far followed the directives of the five-year plans of the government. Much of India's post-liberalization growth has been led by the service sector which today contributes nearly 60percent of GDP. In light of the global economic slowdown, the sustainability of these methods has been questioned. The 'Make in India' initiative by the Government is aimed at enabling a best-in-class manufacturing infrastructure to foster innovation in the manufacturing sector. ${ }^{1,2}$ This scheme is based on the idea of developing India into a global manufacturing hub and attracting investments from around the world, it also aims to leverage India's tremendous export potential. Such a programme is sorely required for the much-needed transformation of the country from a predominantly agrarian society to a modern industrial one. While an industry-focused strategy will ease the pressure off the agriculture sector, it will also strengthen India's standing in the context of a globalized and increasingly industrialized economy. It is imperative for the economy to create new jobs for its population through increasing its manufacturing industry. The inherent labor intensive nature of the Textile industry has the capabilities of providing jobs in the short-run and helps in the development of the Indian economy. This sector offers tremendous employment opportunities for people, especially in the rural regions. The textile sector in India accounts for $10 \%$ of the country's manufacturing production, $5 \%$ of India's GDP, and $13 \%$ of India's exports earnings. Textile and apparel sector is the second largest employment provider in the country employing nearly 51million people directly and 68 million people indirectly in 201516. The progress in manufacturing also has a potential to support the rural and semi-urban industries and help alleviate regional disparities across the country through providing unskilled labor employment.

\section{Make in India}

'Make in India' is an initiative launched by the Government of India to boost multi-national, as well as national companies to manufacture their products in India. It was launched by Prime Minister Narendra Modi on 25 September 2014. After the launch of this scheme, India received US \$63billion in FDI surpassing United States of America and Peoples Republic of China. The main aim of this scheme is to create jobs and development of skill in 25 sectors of the economy. The initiative also aims to manufacture products of higher quality standards and to reduce the impact on environment. The initiative also hopes to attract more capital and technological investment in India. "The Make in India" initiative is based on four pillars, which have been identified to give boost to entrepreneurship in India, not only in manufacturing but also other sectors. ${ }^{3-5}$ The four pillars are
a. New Processes
b. New Infrastructure
c. New Sectors
d. New Mindset

25 sectors have been identified under Make in India initiative, viz.

i. Auto Components

ii. Automobiles

iii. Aviation

iv. Biotechnology

v. Chemicals

vi. Construction

vii. Defense Manufacturing

viii. Electrical Machinery

ix. Electronic System Design and Manufacturing

x. Food Processing

xi. IT and BPM 


\author{
xii. Leather \\ xiii. Media and Entertainment \\ xiv. Mining \\ xv. Oil and Gas \\ xvi. Pharmaceuticals \\ xvii. Ports \\ xviii. Railways \\ xix. Roads and Highways \\ xx. Renewable Energy \\ xxi. Space \\ xxii. Textiles \\ xxiii. Thermal Power \\ xxiv. Tourism and Hospitality \\ xxv. Wellness
}

\section{Benefits of investment in Indian textile industries}

In India raw materials such as cotton, wool, silk, jute and manmade fibres are available in abundance. Labor cost of skilled manpower is low as compare to other major textile producers across globe. The existence of entire value chain for textile production starting from production of natural fibre to the production of yarn, fabric and apparel inside the country gives edge over countries like Vietnam, Bangladesh etc. The existence of traditional sectors in India i.e. hand loom and handicraft. Market access arrangements with Japan, South Korea, ASEAN, Chile while negotiations with EU, Australia, Regional Comprehensive Economic Partnership (RCEP) countries under process. Easily available market which is poised to grow in future with increased penetration of organized retail, favorable demographics and rising income levels. The Integrated Skill Development Scheme aims to train over 2.675 million people up to 2017 , covering all sub-sectors of the textile sector- textiles and apparel, handicrafts, handlooms, jute and sericulture. The Centers of Excellence focused on testing and evaluation as well as resource centers and training facilities have been set up.

\section{Impact of make in india on textile sector}

The ambitious 'Make in India' scheme is already proven boon to the textile sector. With increased penetration of organized retail, favorable demographics and rising income levels are expected to drive textile demand. Already several multi-national companies have invested in India. These include manufacturers Rieter and Trutzschler, and apparel retailers like Zara and Mango (both from Spain), Benetton (Italy), Promod (France), Esprit, Levi's and Forever 21 (all from US). Since the start of this initiative the textile sector growth is expected to grow almost double than the current scenario (Figure 1). ${ }^{6,7}$

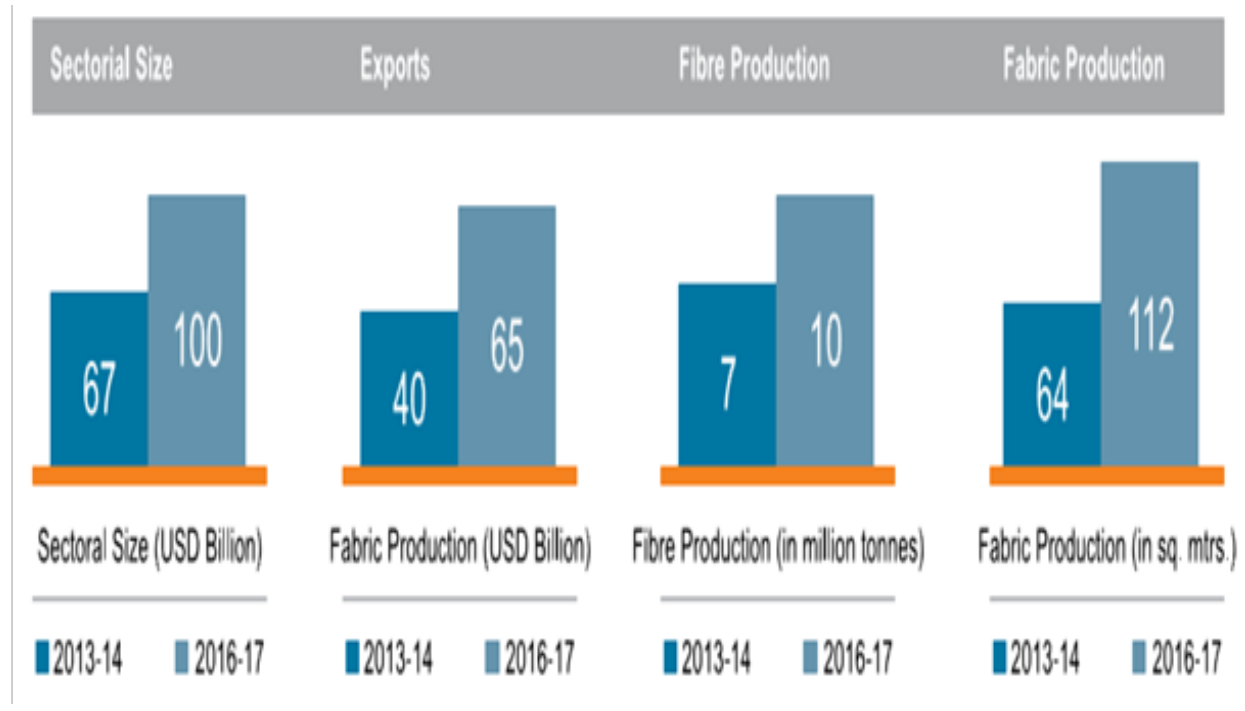

Figure I Estimated growth of the Indian texile industry.

\section{Statistics of textile market in India}

Textile and apparel sector contributes $14 \%$ to industrial production, $4 \%$ to India's Gross Domestic Product (GDP) and constitutes 15\% of the country's export earnings. Textile and apparel sector is the second largest employment provider in the country employing nearly 51million people directly and 68million people indirectly in 2015-16. Textile exports of India stood at USD 40billion in 2015-16. India's fibre production in 2015-16 is 9 million Tonnes in 2015-16 and is expected to reach 10million Tonnes in 2017-18. The total fabric production in India is expected to grow to 69 billion sq.mts by 201718 from 66billion sq.mts in 2015-16.The Indian textiles industry, currently estimated at around US\$ 108 billion, is expected to reach US\$223billion by $2021 .^{8-10}$

India is the largest producer of Cotton in the world with 5,984 million $\mathrm{kg}$ production in 2015-16. India is largest producer of Jute in the world with 9.92 million bales of (180kg each) in 2015-16. In Silk fibre production India is on second position in the world with 28,472 MT in 2015-16. India is of the major producers of Wool in the world with 48million kg production in 2014-15. Indian manmade fibre industries are growing and currently it is a second largest producer of Manmade Fibre and Filament in the world with 2,511millionkg production in 2015-16. 
In staple yarn spinning India is on second position with 50million spindles and 8million rotors in the world. India has a highest installed weaving capacity with more than 4.9 million looms (including 2.4 million handlooms). India contributes $42 \%$ to the textile and apparel export basket of India during 2015-16. Also, it is one of the focus areas of Government of India as the sector has huge employment generation potential.

\section{Policy for textile sector}

The Government of India has launched the following initiatives to strengthen textile production and encourage this industry to cater to the domestic and international market efficiently.

\section{Technology Upgradation Fund Scheme (TUFS)}

TUFS has infused investment of more than USD 41.33 billion in the industry. Support has been provided for modernization and upgradation by providing credit at reduced rates and capital subsidies.

\section{Scheme For Integrated Textile Parks (SITP)}

Scheme will provide funding for infrastructure, buildings for common facilities like design \& training centre, warehouse, factories and plant $\&$ machinery, till now 74 textiles parks have been approved and are at various stages of implementation with 18 parks operational, 32 under implementation. The investment of USD 692million is sanctioned by the government which will create 66,000 jobs.

\section{Integrated Processing Development Scheme (IPDS)}

IPDS is being implemented to make Indian textiles more competitive and environment-friendly.

\section{Integrated Skill Development Scheme (ISDS)}

ISDS plans to bridge that skill gap by training 1.5 million people for which USD 300million has been allocated by the government.

\section{Amended Technology Upgradation Fund Scheme for Textiles Industry (ATUFS)}

ATUFS is designed to provide incentives to entrepreneurs and business owners for upgrading technologies. ATUFS facilities are expected to receive an investment of USD 15billion and create 3 million jobs in the country.

\section{Market Access Initiatives (MAI)}

MAI was launched to promote the Indian exports in a sustained manner. The scheme funds various market studies and surveys to assist exporters.

\section{Market Development Assistance (MDA)}

To encourage exporters to conduct promotional activities for their products.

\section{Technology Mission for Technical Textiles (TMTT)}

TMMT has two mini missions to create a healthy ecosystem for the production of technical textiles in India. The Mini Mission I of the plan aims at standardization, creating common testing facilities and several resource centres with IT infrastructure. Under Mini Mission II, support will be provided to create domestic and export markets for the technical textiles.

\section{Special package for textile and apparel sector}

To boost exports, labor- friendly policies, scaling up the production and to generate over 10 million jobs in the textile industry over the period of next three years.

\section{Implications of Goods and Services Tax (GST) for In- dian textiles sector}

GST will result in 'Fibre-neutrality effect' on the Indian textiles sector, according to the Ministry of Textiles, that means all man-made and natural fibres will be treated equally from the tax point of view.

\section{Key provisions of budget 20 I6-I 7 for textile sector}

a. Basic Custom Duty on certain specialty fibres and yarns has been reduced from $5 \%$ to $2.5 \%$. Basic Custom Duty has been exempted on import of certain fabrics of value equivalent to $1 \%$ of Free on Board (FOB) value of exports in the preceding year for the manufacturing of textile for exports.

b. The Excise Duty of $2 \%$ without CENVAT credit and $12.5 \%$ with Central Value Added Tax (CENVAT) credit has been imposed on branded readymade garments and made up of price USD 15.38 or more.

c. The tariff value of readymade garments and made up articles of textiles has been changed from $30 \%$ of retail sale price to $60 \%$ of retail sale price.

d. The Excise Duty has been increased from 6\% to $12.5 \%$ with CENVAT credit on re-cycled Polyester Staple Fibre and Polyester Filament Yarn.

\section{Recent packages provided to the sector}

The Outlay for Ministry of Textile is of USD 515.39million (including USD 51.5million for North Eastern Region, USD 25.77million for Scheduled Caste Sub-Plan and USD 6.18million for Tribal Sub-Plan) which is mainly for:

i. Amended Technology Upgradation Fund Scheme (USD 227.7million)

ii. National Handloom Development Programme (USD 84.15million)

iii. National Handicraft Development Programme (USD 33.69million)

iv. Development of Woolen Textiles (USD 4.46million)

v. Development of Silk Industry (USD 26.54million)

vi. Power Loom Promotion Scheme (USD 17.7million)

vii. Textile Infrastructure (USD 24.25million)

viii. Research \& Capacity Building including National Institute of Fashion Technology (USD 47.51million)

ix. NER Textiles Promotion Scheme including Scheme for usage of Geo Textile in North Eastern Region \& Scheme for Promoting Agro Textiles in North East (USD 39.88million), etc.

\section{Tax incentives}

A. Presumptive taxation scheme under section $44 \mathrm{AD}$ of the Income Tax Act available for small and medium enterprises with turno- 
ver or gross receipts not exceeding USD 0.15 million has been enhanced to USD 0.30 million.

B. The corporate income tax rate for the next financial year of the companies with turnover not exceeding USD 0.76 million (in the financial year ending March 2015) has been lowered from present rate of $30 \%$ to $29 \%$, plus surcharge and cess.

C. Service tax is exempted on services provided under Deen Dayal Upadhyay Grameen Kaushalya Yojana (DDU GKY) and services provided by Assessing Bodies empaneled by Ministry of Skill Development \& Entrepreneurship.

D. Higher drawback rate has been provisioned from 1.7.2012 onwards under notification No. 41/2012.

\section{State incentives}

a. Apart from the above, each state in India offers additional incentives for industrial projects. Some of the states also have separate policies for the textiles sector.

b. Incentives are in areas like subsidized land cost, relaxation in stamp duty exemption on sale/lease of land, power tariff incentives, concessional rates of interest on loans, investment subsidies/ tax incentives, backward areas subsidies and special incentive packages for mega projects.

\section{Export incentives}

A. Export Promotion Capital Goods Scheme (EPCG)

B. Duty Exemption \& Remission Scheme

C. Merchandise Exports from India Scheme (MEIS)

\section{Area based incentives}

Incentives for units in Special Economic Zones(SEZs)/National

Table I COE with area of excellence in technical textile
Investment \& Manufacturing Zones(NIMZs) as specified in respective acts or the setting up of projects in special areas such as the NorthEast, Jammu \& Kashmir, Himanchal Pradesh \& Uttarakhand.

\section{Incubation centres}

The Ministry has allocated Rs.152crore under the Technology Mission for Technical Textiles for the eight 'Centre of Excellence'. The Centres have facilities for research and development, testing, standardising products and commercial production at the incubation facilities. The Union Government allocated Rs.17.40crore this financial year for setting up incubation centres for technical textiles. Technical textiles are products manufactured for non-aesthetic purposes. This could include protective clothing and textiles used in applications such as automotive and medical. These incubation centres will have plug and play facilities and all the eight Centres of Excellence for technical textiles have established the centres. Following table illustrate $\mathrm{COE}$ with area of excellence in technical textile (Table 1) (Table 2).

\section{Investment plans of leading textile industries in india}

Chiripal group: Chiripal Group is planning to invest USD 174million to bolster its polyester supply chain production. This programme is a part of the overall plans in the next two years, with an investment of around USD 540million for expansion in various sectors in the next two years. Nandan Denim Ltd. is to invest USD 89million at its textile park in Bidaj. Nandan Terry is setting up a USD 75 million terry towel facilities in Ahmedabad district with an initial capacity of 10,696 tonnes per annum. A knitting project involving terry towel manufacturing is also coming up with an investment of around USD 59million at Dholi village in Dholka Taluka of Ahmedabad. The group will invest around USD 194million to expand its spinning and weaving activities under Chiripal Industries Ltd and Shanti Exports Private Ltd. A spinning park, with eleven spinning units and five weaving units, with an investment of USD 22million is also coming up come up at Dholi.

\section{$\begin{array}{llll}\text { S. No COE name and city } \quad \text { Area of excellence } & \text { Fund released } & \text { Progress }\end{array}$} ATIRA, Ahmadabad

Composites

Non-woven and Coated Textiles

Protective

Filters, Acoustic Thermal Insulators, Wipes

Agro textiles and Packaging
PSG College of Technology, Coimbatore Textiles
3.42 crore

Machines procured and Installation is underway.

2.70 crore

Machines procured and Installation is underway

2.87 crore

Construction of Industrial shed completed. Procurement of machinery underway.

2.85 crore

Tenders finalized. Machineries being procured.
5

SASMIRA, Mumbai 
Table 2 Foreign Investors

\begin{tabular}{ll}
\hline S. No & Foreign investors \\
\hline 1 & Rieter (Switzerland) \\
2 & Trutzschler (Germany) \\
3 & Soktas (Turkey) \\
4 & Zambiati (Italy) \\
5 & Bilsar (Turkey) \\
6 & Monti (Italy) \\
7 & Mango (Spain) \\
8 & Promod (France) \\
9 & Benetton (Italy) \\
10 & Espirit (USA) \\
11 & Levi's (USA) \\
12 & CMT (Mauritius) \\
13 & E-land (S. Korea) \\
14 & Nissinbo (Japan) \\
15 & Marubeni (Japan) \\
16 & Skaps (USA) \\
17 & Ahlstorm (USA) \\
18 & Terram (UK) \\
19 & Strata Geosystems (USA) \\
20 & Marks \& Spencer (UK) \\
21 & Zara (Spain) \\
22 & Forever 2I (USA) \\
\hline & \\
\hline 1 &
\end{tabular}

Renfro India: It is India's largest sock manufacturer; company was acquired by Renfro Corporation, USA in 2002. It has an annual turnover of USD 29.65 million and is growing at an annual rate of $15 \%$ to $20 \%$. With 900 employees, the company's capabilities cover all stages of the product life cycle from design and manufacturing to sales and marketing. Renfro India plans invest USD 30million to set up its third plant in Gujarat, and expand its footprint in the Indian market. Currently, it has manufacturing facilities in Pune and Nashik.

GAP inc.: GAP is an American multinational for clothing and accessories, founded in San Francisco in 1969. GAP opened their flagship store in Delhi in May 2015, and currently has three stores in Delhi \& NCR and one in Bengaluru. GAP plans to come up with 40 stores in the next four years, out of which, 10 stores will be set up by mid 2016 . Each store will entail an investment of USD 13.33million.

H \& M: Hennes \& Mauritz (H\&M) is a Swedish multinational retai1-clothing company with stores in 59 markets worldwide, and online shopping facilities in 21 countries. H\&M plans to double the number of its stores in the country from six to 12 by year-end. The Indian unit of H\&M AB, which entered India in October 2015 and currently operates stores in Delhi, Punjab and Bengaluru, will expand to Mumbai, Pune and Chennai. The group plans to invest USD 108million in India and open 50 single brand retail outlets across India in the next few years.
Sangam India: Sangam India Ltd. is incorporated in 1984; today it has over 10,000employees. The group has over 2, 00,000 spindles and 3,000 rotors for producing PV dyed yarn, cotton and OE yarn. It is the largest producer of PV dyed yarn in Asia at a single location. Sangam India is a forerunner in manufacturing ready to stitch fabric, with the annual capacity to produce 30 million meters of fabric and 40 million meters of denim.

\section{Conclusion}

The Indian textile industry stands to benefit immensely from the ambitious "Make in India" initiative. The vision of this scheme has the potential to repair the segments perception and the country's involvement in the world textile scenario. India is the only country in the world that offers the unique combination of democracy, demography, and demand. This combined with the newest international strategy of the government will lead to more job creation, boosting the national economy and give the Indian economy global recognition. The textile sector has the capability to contribute highest to the Indian economy by providing more jobs and contributing to the overall GDP. With a $100 \%$ FDI for the textile sector and other provisions provided by the government, the 'Make in India' campaign will surely proof beneficial to the manufacturing unit of the textile sector. It is the need of today that 'Make in India' campaign become the philosophy of the country and national movement.

\section{Acknowledgements}

None.

\section{Conflict of interest}

Author declares there is no conflict of interest in publishing the article.

\section{References}

1. Shambhavi Sawhney. 'Make in India' and its Economic Impact on the Indian Handloom Sector' JEL classification: R28, R58, O13, O14. Lampert Institute for Civic and Global Affairs. New York, USA; 2016. p. 1-33.

2. Textiles \& Apparel Sector. Ministry of Textiles Department of Industrial Policy and Promotion. 2016. p. 1-12.

3. Sandip Das "Make In India"-A Boost To The Manufacturing Sector.

4. Make in India: Sectors in Focus-Part 1.

5. Textile magazine. Make-in-India'-A Big Boost To Manufacturing Sector. 2016.

6. Economics Knowledge Banking, Yes Bank. 'Make in India'-Pressing the Pedal. India: Yes Bank 1td; 2015. p. 1-68.

7. 'Make in India' rolled out for textile \& garment industry. Fibre2Fashion Pvt. Ltd.

8. Textile Industry \& Market Growth in India. 2017.

9. Impact of 'Make in India' on the Denim Manufacturing Industry. India: Suryalakshmi Cotton Mills Ltd; p. 1-4.

10. Vision, Strategy And Action Plan For Indian Textile And Apparel Sector. 